THE POWER BEHIND EMPOWERMENT:

IMPLICATIONS FOR RESEARCH \& PRACTICE

by

Cynthia Hardy

Professor

Faculty of Management

McGill University

1001 Sherbrooke West

Montreal, Canada, H3A 1 G5
Sharon N. Leiba

Assistant Professor

Department of Management

Concordia University

1455 de Maisonneuve West

Montreal, Canada H3G 1M8

March 19th 1997

The authors acknowledge the support of the Social Sciences \& Humanities Research Council of Canada and McGill University. They also thank Martin Evans for his helpful comments on an earlier draft. 


\title{
THE POWER BEHIND EMPOWERMENT: IMPLICATIONS FOR RESEARCH \& PRACTICE
}

\begin{abstract}
The 1990s have been called the "empowerment era”, yet growing evidence suggests that empowerment programs often fail to meet the expectations of both managers and employees. To provide a better understanding as to why empowerment programs often fail and to suggest how such failures may be averted, we examine the power behind empowerment. Ironically, although power and empowerment are inextricably linked, much of the work on empowerment in the business literature has been devoid of any discussion of power. We present a four dimensional model which shows the multi-faceted way in which power works. In it, we observe the similarities and differences in the ways that different theorists have approached the study of power, notably those ascribing to mainstream, critical, and Foucauldian perspectives. We then use this power model as a lens with which to examine empowerment practices in business. This analysis suggests a number of possible reasons for the failure of business empowerment programs and provides directions for future research and practice which might address these shortcomings.
\end{abstract}




\section{INTRODUCTION}

Initiatives to involve employees in organizational decision-making are as old as industrial democracy, which can be traced back to the last century (Hancock et al., 1991; Lichtenstein \& Howell, 1993; IDE International Research Group, 1993), and as recent as team building (e.g., McCann \& Galbraith, 1981), participation (e.g., Leana, 1987; Leana et al., 1992), and total quality management (e.g., Dean \& Bowen, 1994; Spencer, 1994; Waldman, 1994). The latest variation on this theme has been termed “employee empowerment”. The popularity of this latest approach led some writers to hail the 1990s as the "empowerment era”, because businesses appeared to be taking significant, observable steps toward liberating "the creative and innovative energies of employees" benefitting "shareholders through improvements in the bottom line, customers through value and service, suppliers through more effective partnership agreements and employees through a higher quality of worklife” (Gandz, 1990: 74; also Burke, 1986; Conger \& Kanungo, 1988; Thomas \& Velthouse, 1990; Bowen \& Lawler, 1992; Ford \& Fottler, 1995).

Growing evidence suggests, however, that empowerment programs often fail to meet the expectations of either managers or employees (e.g., Bernstein, 1992; Brown, 1992; Matthes, 1992; Eccles, 1993; Eccles \& Nohria, 1993; Barker, 1993; Parker, 1993; Cullen \& Townley, 1994). To explore why empowerment programs may fail and to suggest how such failures may be averted, we examine the power behind empowerment. Ironically, although power and empowerment are inextricably linked, much of the work on empowerment in the business literature has been devoid of any discussion of power. We present a four dimensional model to show the multi-faceted way in which power works. We also observe the similarities and differences in the ways that different theorists have approached the study of power, notably those 
ascribing to mainstream, critical, and Foucauldian perspectives. (Readers should note that we use these terms to refer loosely to broad bodies of literature marked by different assumptions and epistemologies, hence the italics marks). We then use this model as a lens through which we examine empowerment practices in business. Next we explore the implications resulting from this analysis, suggesting a number of possible reasons for the failure of business empowerment programs and providing directions for future research and practice.

\section{UNDERSTANDING POWER}

In this section, we attempt to rectify the omission of power from discussions of empowerment by discussing power as a complex, multi-dimensional concept. Note that we use the term dimension deliberately following Lukes’ (1974) work, building on his model by adding a fourth dimension and applying it to the management literature and to empowerment practices. Our model indicates that power is exercised, in the first dimension, by using various resources to influence the outcome of decision-making processes; in the second dimension, by controlling access to those processes; and, in the third dimension, though hegemonic processes, by which we mean the legitimation of power through cultural and normative assumptions (e.g., Hyman \& Brough, 1975). The first two dimensions rest on the assumption that power is mobilized only in the face of conflict and opposition, whereas the third dimension, through its grounding in critical theory, acknowledges that power can be used to ensure that such conflict never arises. The fourth dimension of our model (Hardy, 1994) derives from recent developments in the study of power, notably those of Foucault (Foucault, 1977, 1980, 1982, 1984). The inclusion of this fourth dimension, which draws attention to the limits of power, enables us to explore aspects of power that do not normally appear in the mainstream literature on power (let alone in the work on empowerment), allowing us to draw out their implications for research and practice. Our focus is 
thus on the different ways in which power works (cf. Clegg 1975, 1989; Frost, 1987; Frost \& Egri, 1989; Bradshaw-Camball \& Murray, 1991) and their implications for empowerment, not on the ontological and eptistemological debates between the adherents of the various approaches.

\section{The First Dimension}

Lukes (1974) linked the first dimension of power to early studies of community power (e.g., Dahl, 1957; Polsby, 1963). In these early studies, researchers analyzed key decisions that seemed likely to illustrate the power relations prevailing in a particular community. The object was to determine who influenced the outcome of these decisions: if it was the same groups, the community could be said to be ruled by an elite; if, in contrast, a variety of different groups were able to influence decision outcomes, then the community could be termed pluralist. Several assumptions underlay this research: it was presumed that all individuals are aware of their grievances and act upon them by participating in the decision-making process and using their influence to determine key decisions; that the exercise of power occurs only in decisions where conflict is clearly observable; that conflict is resolved during the decision-making process (Bachrach \& Baratz, 1963; Lukes, 1974; Parry \& Morriss, 1975).

An examination of early management studies of power shows that, although conducted separately and with a different rationale, management scholars adopted a similar view of power as the pluralists. Many of these management studies focussed on uncovering the sources of power that allowed actors, who did not possess legitimate authority, to influence decision outcomes (e.g. Thompson, 1956; Mechanic, 1962; Crozier, 1964). The strategic contingencies theory of intra-organizational power (Hickson et al., 1971) argued that strategically contingent sub-units are powerful because they are less dependent on others and can cope with greater amount of uncertainty as long as they are central and not easily substitutable. The resource 
dependency view (Pfeffer \& Salancik 1974, Salancik \& Pfeffer 1974) links power to the control of scarce resources on which others depend, such as information, expertise, credibility, prestige, access to higher echelon members, and the control of money, rewards and sanctions (French \& Raven 1968; Pettigrew, 1973; Pfeffer, 1981). Some management writers questioned whether possessing scarce resources of various kinds was, in itself, enough to confer power (Pettigrew, 1973). They argued that actors must also be aware of the contextual pertinence of the different resources they possess and deploy them accordingly, employing the term "politics" to describe this process of power mobilization (Pettigrew, 1973; Hickson et al., 1986).

The parallels between this stream of research, which we term mainstream management, and the work of the pluralists are the following. First, both pluralists and mainstream management researchers challenged existing models of decision making: the pluralists refuted elitist views of decision-making predominant in sociology; while mainstream management researchers challenged the rational model of decision-making that existed in much of the management literature. Second, both argued that decision outcomes were influenced by actors' inclination and expertise in using power and both were interested in how power was exercised to influence decision outcomes. Third, both mainstream management researchers and pluralists employed similar definitions of power, seeing it as the ability to get others to do what you want them to, if necessary against their will (Weber 1947) or to do something they otherwise would not do (Dahl 1957). Thus, like the pluralists, mainstream management writers believed that the exercise of power occurred only in decisions where conflict was clearly observable (e.g. Pettigrew, 1973; MacMillan, 1978; Pfeffer, 1981, 1992; Narayaran \& Fahey, 1982; Gray \& Ariss, 1985; Schwenk, 1989). 
In these ways, the mainstream management work on power converges, theoretically, with Lukes' (1974) description of the first dimension of power. Both adopt a behavioural approach that focusses on the overt exercise of power in the decision making arena. Both are functionalist in examining how power functions in determining decision outcomes (see Bachrach \& Baratz, 1962; Lukes, 1974; Hardy \& Clegg, 1996). Finally, both assume conflict to be a necessary condition for the exercise of power.

\section{The Second Dimension}

The second dimension of power developed as researchers began to question pluralist assumptions, in particular, the idea that decision-making arenas were open to anyone with an interest in them and, therefore, nonparticipation reflected satisfaction and consensus (Bachrach \& Baratz, 1963; Lukes, 1974). Researchers started to consider the possibility that conflict can exist without necessarily being articulated through official channels. Subsequent work examined how full-and-equal participation might be constrained by "the suppression of options and alternatives that reflect the needs of the nonparticipants. It is not necessarily true that people with the greatest needs participate in politics most actively -- whoever decides what the game is about also decides who gets in the game” (Schattschneider, 1960: 105). Specifically, Bachrach \& Baratz observed that issues could be excluded from decision-making, and the agenda confined to "safe" questions, which they called “nondecision-making”, because it allows the more powerful actors to determine outcomes from behind the scenes.

Nondecision-making is typically associated with attempts by dominant groups to protect the status quo (e.g., Crenson, 1971; Hunter, 1980), but the same processes can sometimes be manipulated by less powerful groups to their advantage. For example, in 1990, the lone Native member of the Manitoba legislature blocked the passage of constitutional agreement between 
federal and provincial governments in Canada (and from which all aboriginal groups had been excluded) by using complex parliamentary procedures. Alternately, similar processes can be manipulated as a means of changing the power entrenched in the status quo by extending access to decision-making arenas and agendas. For example, committees may be established with members of the "new guard" to bring about change; mandates may be widened; and membership may be made more democratic (Hardy, 1994; Hardy \& Redivo, 1994).

While the work on nondecision-making broadened the research agenda, it continues to operate on similar assumptions as the one-dimensional view of power. Specifically, it continues to assume that some form of conflict is necessary for power to be exercised (Lukes, 1974). Bachrach \& Baratz retained a behavioural focus which was “very much upon 'issues' about which 'decisions' have to be made, albeit 'nondecisions': power in this view stands close to action, using the bases of power to prevent access to the decision-making arena and hence ensure compliance” (Ranson et al., 1980: 8).

Thus, from a theoretical perspective, the second dimension and the first dimension converge: both focus on the exercise of power in or around the decision-making arena as part of a deliberate strategy to achieve intended outcomes. Although the power mobilized through decision processes may be less visible than the power mobilized through resources -- since opponents may be sidelined rather than directly confronted -- it is still premised on the existence of conflict and opposition.

\section{The Third Dimension}

By specifying conflict as a prerequisite of nondecision-making, Bachrach \& Baratz overlooked the possibility that power might be used to prevent conflict from emerging in the first place. Lukes (1974: 24) pointed out that power is often used to shape peoples' 'perceptions, 
cognitions, and preferences in such a way that they accept their role in the existing order of things, either because they can see or imagine no alternative to it, or because they view it as natural and unchangeable, or because they value it as divinely ordained and beneficial.” According to this view, the study of power cannot be confined to observable conflict, to the outcomes of decisions, or even to suppressed issues. It must also consider the question of political quiescence; why grievances do not exist; why demands are not made; why conflict does not arise, and why resistance does not occur, since such inaction may also be the result of power. In other words, the study of power must also recognize that we may be “duped, hood-winked, coerced, cajoled, or manipulated into political inactivity” (Saunders, 1980: 22). The third dimension of power is thus substantively different in the assumptions it makes regarding conflict: power is used not simply to defeat conflict but to prevent it from arising in the first place (Ranson et al. 1980; Hardy, 1985a).

By acknowledging the role of power in preventing conflict, the third dimension acknowledges the possibility of perpetuating the status quo by societal and class mechanisms. In this regard, Lukes' work is characteristic of critical theory (see Hoy, 1986), a term used here to refer to a diverse body of research and not only the members of the Frankfurt School (cf. Alvesson \& Willmott, 1992a). Critical writers point out that power is ideological, as well as economic and structural. Through the production of everyday beliefs and practices, power is used to produce apparent consensus and acquiescence, replacing visible controls by hidden cultural forms of domination (Deetz, 1992a; also Perrow, 1979; Fox, 1973; Mills, 1956). Such “radical” perspectives draw on Gramsci’s concept of ideological hegemony, where “a structure of power relations is fully legitimized by an integrated system of cultural and normative assumptions” (Hyman \& Brough, 1975: 199). In short, critical theorists are interested in exposing how power, 
concealed in the legitimate status-quo trappings of society's structures, rules, class mechanisms, and cultures, prevents conflict from arising (Clegg, 1989).

Some work informed by critical assumptions has been carried out in the context of management and organization studies. For example, Perrow (1979) focussed attention on unobtrusive controls, conceptualizing organizations as tools; some scholars have investigated how power is hidden in deep structures (e.g., Clegg, 1975; Frost \& Egri, 1989); others have explored how managers use power to manage meaning and distort communication (Pettigrew, 1979; Hardy, 1985a,b; Forester, 1989, 1992). Critical researchers have also argued that power is embedded in organizational structures and meanings (e.g., Ranson et al., 1980); in organizational cultures (e.g., Martin, 1992; Willmott, 1993); ideologies (e.g., Alvesson, 1984); and in the legitimacy of organizational arrangements (e.g., Astley \& Sachdeva, 1984). $\quad$ However, much of the management literature on power falls into the mainstream category because it makes conflict a pre-condition for the use of power, dismissing the possibility that power might be used to prevent conflict. For example, Pfeffer (1981) distinguished "sentiment” (attitudinal) from "substantive" (behavioural) outcomes of power. Sentiment outcomes refer to the way people feel about substantive outcomes and are influenced by the symbolic aspects of power, such as the use of political language, symbols and rituals; subtantive outcomes, according to Pfeffer, are determined by resource dependencies. Despite discussing the impact of symbolic power on attitudes, Pfeffer stopped short of acknowledging that symbolic power could be used to achieve substantive outcomes by influencing attitudes and preventing conflict and opposition. Instead, he argued that symbolic power was only used post-hoc to legitimize outcomes already achieved by resource dependencies. Other mainstream management writers have been similarly reluctant to acknowledge the existence of organizational hegemony: researchers of organizational culture 
have gone to considerable length to avoid its association with power and politics (see Izraeli \& Jick, 1986; Hollway, 1991); while Weiss \& Miller (1987) have argued that definitions of ideology in the management literature have been purged of political connotations (also see Beyer et al., 1988). Yet, if symbolic, cultural and ideological aspects of power can help to "quieten” opposition ex post, why not use them ex ante to prevent opposition from arising in the first place, and secure substantive outcomes that way?

It is writers in the critical tradition, rather than mainstream management theorists, who have constructed a picture of how the third dimension of power works in organizations. This work shows how power can be employed by dominant interest groups to legitimize their demands and to "de-legitimize" the demands of others by managing meaning (Pettigrew, 1979). These actors can use power to prevent others from making challenges by legitimating existing power positions, and portraying their positions as beneficial, acceptable, or inevitable (Frost, 1987). In this way, political issues may be obscured and "depoliticized", in a relatively unobtrusive manner, by reducing individuals' awareness of their disadvantaged positions and the existence of political issues (Hardy, 1985a,b), enabling dominant actors to achieve their desired outcomes precisely because there is not resistance to them. Several writers have argued that the third dimension is not the exclusive domain of dominant actors, pointing out that all actors have some ability to manage meaning (Giddens, 1979; Clegg, 1989). Accordingly, the third dimension of power can also be mobilized by subordinate groups and used as a form of resistance. In this case, it may take on a more visible form, as meaning is managed to challenge the status quo and raise political consciousness, thereby creating the will to resist.

In summary, the critical approach to power in organizations is substantively different, in terms of the assumptions it makes, from the mainstream management research described earlier 
under the first dimension. Critical theorists depict so-called legitimate power as domination, which represents the use of power to prevent conflict. Actions taken to challenge this use of power are construed as resistance to domination (see Barbalet, 1988; also see Hardy \& Clegg, 1996). The critical approach thus differs significantly from mainstream management theorists who adopt a functional, behavioural approach that distinguishes "illegitimate” power from "legitimate" authority; and who maintain that conflict is a prerequisite of power use.

\section{The Fourth Dimension}

Lukes (1974) stopped at the third dimension. In the last twenty years, however, a number of developments have occurred in the study of power, suggesting the existence of a fourth dimension (Hardy, 1994). ${ }^{1}$ Notable among many important contributions is the work of Michel Foucault (Foucault, 1977, 1980, 1982, 1984; Dreyfus \& Rabinow, 1982; Smart, 1985, 1986; Turner, 1990), which has been applied to organizations by such writers as Knights and colleagues (Knights \& Willmott, 1989; Knights \& Morgan, 1991; Knights, 1992; Kerfoot \& Knights, 1993; Clegg, 1989; Alvesson \& Willmott, 1992a,b; Deetz, 1992a,b). A number of important points about power are raised in this body of work.

First, Foucault's work contests the concept of sovereign power that underpins the first three dimensions. He repudiates the idea of an isolated agent who possesses and mobilizes a battery of power sources that can be used to produce particular outcomes, be they managerialist or emancipatory. Instead, he conceptualizes power as a network of relations and discourses which capture advantaged and disadvantaged alike in its web (Deetz, 1992a,b). Actors may have intentions concerning outcomes, and may mobilize resources or engage in the management of

\footnotetext{
${ }^{1}$ While the differences between critical theory and postmodernism have been subject to some debate, we follow the example of Alvesson \& Deetz (1986), and present them as two separate categories.
} 
meaning with the idea of achieving them, but pulling these "strings" of power does not necessarily produce these desired outcomes.

People know what they do; they frequently know why they do what they do; but what they don't know is what what they do does (Foucault quoted in Dreyfus \& Rabinow, 1982: 187).

According to this view, then, power is no longer a convenient, manipulable, deterministic resource under the control of autonomous, sovereign actors. Instead, all actors are subjected to “disciplinary” power, a prevailing web of power relations which resides in every perception, judgement and act (e.g., Deetz, 1992b), and from which the prospects of escape are limited for dominant and subordinate groups alike.

Second, Foucault draws attention to how the subject is socially produced by the system of power which surrounds it (Knights \& Willmott, 1989; Knights \& Morgan, 1991; Knights, 1992). The individual is not a distinct, autonomous actor, a fixed, objective entity or a stable constellation of essential characteristics. Instead the individual is a socially constituted, socially recognized, category of analysis who has multiple fragmented identities; identities which are salient only insofar as they are socially recognized (e.g. Hassard, 1993; Rosenau, 1992). Thus the subject is not a "given" but "produced historically, that is, constituted through correlative elements of power and knowledge” (Townley, 1993: 522).

Third, as the status of the subject is challenged so, too, is that of the researcher. Rather than viewing the researcher as all-knowing, all-seeing and objective, this perspective draws attention to the relation between the researcher, the research process, and the "knowledge” produced (e.g., Hassard, 1993: Denzin \& Lincoln, 1994). The researcher is no disinterested observer, but simply another product of the social and historical positioning of particular 
intellectual frameworks who can only produce knowledge already embedded in the power of those very frameworks. Because no privileged position exists from which analysis might arbitrate, a Foucauldian view of power differs from critical theory. While the latter suggests that one can escape regimes of power through knowledge, the former denies that knowledge can ever be separated from the effects of power (Mumby, 1992). It challenges the claim of critical theorists to discover truths missed by others (Hoy, 1986; Cooper \& Burrell, 1988) and questions their role as arbiters of “objective” interests (Giddens, 1979; Laclau \& Mouffe, 1987). In other words, according to Foucault, knowledge does not strip away the effects of power to reveal the "truth"; all that knowledge accomplishes is to embody new and different forms of power. Not only is there no autonomous subject waiting to be liberated through critical awareness; but it also erroneous to assue that emancipation can be achieved simply through knowledge gained through critical reflection.

Fourth, Foucault's work illuminates the limitations of resistance. In producing identity, power transforms individuals "into subjects who secure their sense of what it is to be worthy and competent human beings” (Knights \& Morgan, 1991: 269). In other words, the network of power provides the subject with meaning. To resist this power involves personal costs, as the individual is required to repudiate the positive effects of power, such as a sense of him or herself, as part of the emancipatory process. A critical questioning of one’s beliefs may "estrange the individual from the tradition that has formed his or her subjectivity” (Alvesson \& Willmott, 1992a: 447). Second, because prevailing discourses are experienced as reality, alternative discourses are difficult to conceive of, let alone enact (Ashley, 1990). More common are attempts to refute, challenge, modify or amend existing discourses. In such cases, resistance can often only be conceived of in terms of prevailing discourses and is subsequently "colonized" by them. Thus 
existing power relations are reinforced rather than overthrown them (Clegg, 1989; Knights \&

Willmott, 1989; Knights \& Morgan, 1991); thereby limiting the prospects for liberation (e.g., Said, 1986; Walzer, 1986; White, 1986; Sawicki, 1991).

In this regard, Foucault's work reflects a broader body of postmodern and poststructuralist literature. While the use of the term Foucauldian is used here to refer primarily to the work of Foucault on power, it is not divorced from the broader panoply of postmodern approaches. Postmodern approaches challenged the idea of the "grand narrative” framing history by insisting that, instead, there are the local, fragmented narratives of everyday lives; in the place of the "individual", with a stable constellation of essential characteristics, stands the subject, a socially constituted, category of analysis; instead of the disinterested researcher stands simply another subject, embedded in the prevailing power relations and discourses like everyone else (see Jencks, 1989; Laclau, 1988; Hassard, 1993; Rosenau, 1992).

\section{Summary: The Four-dimensional Model of Power}

This four-dimensional model (Table 1) highlights a number of issues concerning the way in which power operates and the assumptions underlying different approaches to the study of power. Our model suggests that power can work at a number of different levels (cf. Clegg, 1975, 1989: Frost, 1987; Frost \& Egri, 1989; Bradshaw-Camball \& Murray, 1991). On the surface, power is exercised through the mobilization of scarce, critical resources, and through the control of decision-making processes. At a deeper level, power is exercised by managing the meanings that shape others' lives. Deeper still, is the suggestion that power is embedded in the very fabric of the system; it constrains how we see, what we see, and how we think, in ways that limit our capacity for resistance.

[Table 1 here] 
By broadening our understanding of power, it becomes easier to understand how power is mobilized by dominant actors. In Table 2, the dominant actor (“A”) prevails over the subordinate actor ( "B”) by using resource interdependencies to influence decision outcomes (in the first dimension); controlling decision-making processes to limit access and agendas (in the second); and managing meaning to create legitimacy for an issue and prevent conflict (in the third dimension). The fourth dimension suggests that while some actors may derive certain advantages from the power relations embedded in the system, they can neither control them nor escape them.

\section{[Table 2 here]}

The model also clarifies the conditions necessary for empowerment. In Table 2, B loses out to $\mathrm{A}$, in the first dimension, by being unable either to procure or deploy critical resources; in the second, by being unable to secure access to the decision-making forum; and in the third, by being unaware of political issues. In the fourth dimension, both B and A are part of a system that prevails over them both: despite A’s apparent dominance, B may stll derive certain benefits from the overall network of power relations. By understanding how B fails to influence outcomes, we learn how B might be empowered: resources must be acquired to influence decision outcomes (first dimension); access to decision-making processes must be secured (second dimension); and political consciousness must be heightened so that B is aware of any political actions, such as the management of meaning, on the part of others (third dimension). In this way, B is both cognizant of any domination and, in the event of a decision to resist, is able to do so. The fourth dimension indicates that the prospects for empowerment, in the sense of freedom from power effects, are limited for both A and B. “True” empowerment will not be achieved without a radical metamorphosis of the system, which cannot be achieved by actors who are inevitably entwined 
within it and which in any case, as Foucault would argue, would simply be replaced by another set of power relations. Nonetheless, the acquisition of the other three dimensions of power may provide B with benefits not previously experienced. The following section explores the implications of this power model for business empowerment practices.

\section{UNDERSTANDING EMPOWERMENT}

In this section of this paper, having explored power, we turn our attention to empowerment. We first describe business empowerment practices. Next we employ our power model as a framework to enable us to explore management's transfer of the dimensions of power.

\section{Business Empowerment Practices}

Senior managers usually have instrumental reasons for implementing empowerment programs (Eccles, 1993): rarely are they simply to enhance morale or democratize the organization but, ultimately, to improve productivity, lower costs, or raise customer satisfaction (e.g. Bell \& Zemke, 1988; Von der Embse, 1989; Early, 1991; Goski \& Belfry, 1991; Eisman, 1991; Schlossberg, 1991; Shelton, 1991). "The purpose of shifting decision making to the employees is not to remove managers totally from making decisions, or to turn the operation into a democracy” (Odiorne, 1991: 66). Consequently, empowerment may be part of a broader initiative, such as continuous improvement (Beatty \& Ulrich, 1991), total quality management (Dean \& Bowen, 1994; Spencer, 1994; Waldman, 1994), and even downsizing (Stopford \& Baden-Fuller, 1990; Feldman \& Leana, 1994; Freeman, 1994) that are intended to improve organizational effectiveness and enhance competitive advantage (Lawler, 1992; O’Connor, 1993).

Empowerment works, according to theorists, in two ways. The relational approach to empowerment (Conger \& Kanungo, 1988) aims at reducing the dependencies that make it 
difficult to get the job done by delegating power and authority (e.g. Burke, 1986; Lawler, 1992). Advocates believe it improves performance because employees, who thrive on stress and are keen to perform above and beyond the call of duty, will take risks to pursue new opportunities and mobilize the power delegated to them for the benefit of the organization (Bell \& Zemke, 1988; Topaz, 1989/90; Block, 1990; Kizilos, 1990; Velthouse, 1990; Beatty \& Ulrich, 1991; Humphrey, 1991). Such practices decentralize power by allowing employees to take part in decision making (Stewart, 1989; Kizilos, 1990; McKenna, 1991a,b; Bowen \& Lawler, 1992; Lawler, 1992). For example, self managing teams may be formed to allow workers to set performance standards and monitor performance; schedule the work; select their own equipment; participate in recruitment decisions; and deal with co-worker discipline and absenteeism ( Sherwood, 1988; Manz, 1990; Beatty \& Ulrich, 1991; Schaeffer, 1991; Sheridan, 1991a,b). Where such changes are made, steps are usually taken to ensure that subordinates do not use their increased power to pursue parochial objectives at the expense of the organization (Schaeffer, 1991). Employees are typically permitted to take decisions only within specified policies and procedures set by management (Topaz, 1989/90; Brymer, 1991; Humphrey, 1991; Eccles, 1993). These controls are referred to as strategic alignment (Belasco, 1989; Velthouse, 1990; Penzer, 1991). For example, while senior managers may solicit employee input concerning the appropriate performance standards (Eisman, 1991: 218), they usually decide on the organizational goals and form of compensation in relation to which these standards are developed (Penzer, 1991). Consequently, decentralized performance appraisals are underscored by a clear understanding of job responsibilities and measurements for success. Alignment can be reinforced by rewards that provide a clear link between individual and organizational goals; the communication of a shared vision; and training and education, all of which help to heighten 
employees’ awareness of strategic business objectives (Velthouse, 1990; Eubanks, 1991;

Fleming, 1991; Welter, 1991a,b; Lawler, 1992). Employees are taught "not only about their immediate job (i.e. what problems to look for and how to fix them) but the reasons and the processes behind it, and its effect on the bottom line, as well” (Penzer, 1991: 98). Similarly, training in group dynamics, interpersonal communication, leadership, and group problem-solving can also increase commitment to organizational goals. (Carr, 1991; McKenna, 1990; Gonring, 1991; Doyle, 1990).

In contrast to the above, the motivational approach to empowerment advocated by other management theorists (e.g., Conger \& Kanungo, 1988; Thomas \& Velthouse, 1990) relies on empowerment practices that typically involve considerably less delegation of power; instead, the emphasis is on open communication and inspirational goal setting to increase commitment and involvement (Conger \& Kanungo, 1988). For instance, advocates of the motivational approach recommend setting attainable objectives that employees can achieve in order to provide opportunities for enactive attainment; using exemplary co-worker and supervisory role models as a form of vicarious learning; giving words of encouragement and feedback to persuade verbally individuals that they are capable; and providing emotional support to offset stress and anxiety, thereby securing positive forms of emotional arousal (Thomas \& Velthouse, 1990). Although jobs may be redesigned under the motivational approach, the primary aim is to provide feelings of ownership, responsibility, and capability (Sheridan, 1991a,b; Eccles, 1993).

By helping employees feel that they have power over significant aspects of their work, and by enabling them to develop a sense of pride and ownership in their work and in the organization (e.g. Kizilos, 1990; Conger, 1989; Feldman, 1991; Schlossberg, 1991), empowerment is thought to leave employees optimistic, involved, committed, able to cope with 
adversity, and willing to perform independently and responsibly (e.g. Conger \& Kanungo, 1988;

Thomas \& Velthouse, 1990; Velthouse, 1990; Shelton, 1991; Block, 1990; also see Porter \& Lawler, 1968). In short, it is thought that the motivational approach to empowerment will improve self-efficacy (Bandura, 1986): the individual's belief that she or he can do the job. Selfefficacy has been repeatedly linked to effective performance (Conger \& Kanungo, 1988; also see Vroom, 1964). The intent in focussing on it is to counter feelings of powerlessness, which are viewed as the major impediment to performance, regardless of whether or not the practices involve any significant delegation of power and authority.

Empowerment programs as recommended in the management literature thus represent a complex set of organizational changes (Leiba \& Hardy, 1994), which are not necessarily all implemented within the context of an individual program (Brown, 1990). Whether the changes include enhancing feelings of self-efficacy through motivational techniques, modifying changing the broader working environment to decentralize power, or incorporating elements of both, depends on which approach is being advocated. To understand more about the political dynamics of such business empowerment practices, we must turn to our power model. As we will discuss, each dimension offers additional insight into both the scope and limits of business empowerment practices.

\section{Business Empowerment Practices: the First Dimension of Power}

As far as the first dimension of power is concerned, business empowerment practices transfer some resources (first dimension) to employees. But, as noted above, senior managers often retain control of many important resources, especially the right to hire, fire, promote, hand out rewards, and control budgets (Stewart, 1989; Bernstein, 1992; Eccles, 1993; Vloeberghs \& Bellans, 1996), rather than handing such resources over to employees in the manner advocated by 
Cardy et al., 1995). Thus, the control of at least some of the resources associated with the first dimension of power remains with existing powerholders. Moreover, there is little discussion about how resources related to either the value created by empowerment, or the incentives for increased effort and responsibility should be assessed and/or distributed (Delbridge et al., 1992).

\section{Business Empowerment Practices: the Second Dimension of Power}

Empowered employees may secure access to some decision-making processes (second dimension) from which they were previously excluded. However, uItimate control of these processes usually rests with senior managers, who set the parameters within which subordinates may operate (Stewart, 1989). Because senior management also continues to set the agenda, usually improved performance and profitability (O’Connor, 1993), and to determine the strategic direction of the company, the future "is not participative but rather dictatorial” (McKenna, 1990: 18). So, while some elements of the first and second dimensions of power are handed over to employees, managers continue to control other aspects of these dimensions.

\section{Business Empowerment Practices: the Third Dimension of Power}

Empowerment practices appear to rely on the increased use of the third dimension of power by management, such as an emphasis on selection, socialization, and socializing to legitimate organizational goals (Stewart, 1989; Barker, 1993; Parker, 1993). Increased communication promotes organizational priorities by instilling shared conceptions of these goals among subordinates (Roberts, 1991; Lawler, 1992). Empowerment terminology reduces conflict by emphasizing consensus and cooperation, through such terms as “associates”, "team members”, “players”, and “coaches” (Carr, 1991; Welter, 1991a,b). Managerial control is reinforced through the language of the team effort (Parker \& Slaughter, 1988; Deetz, 1992b; Barker, 1993; Parker, 1993). Such peer pressure is often more effective than managerial threats. 
"Workers are less likely to call in sick if they have to face team members the next morning” (Manz, 1990: 21). Individuals who oppose empowerment are often “delegitimized” by being labelled “neanderthals” or “dinosaurs” (Ledford, 1993). Dissenters, if they are not fired, may be marginalized as uncooperative, or in need of additional education or training (O’Connor, 1993, 1995).

In this way, empowerment can be viewed as an exercise in the management of meaning to enhance the legitimacy of organizational goals and to influence behaviour unobtrusively. By managing meaning and using power to create the perception that organizational and employee interests converge (e.g. Foxman \& Polsky, 1991; Kizilos, 1990; Goski \& Belfry, 1991; Velthouse, 1990), empowerment programs reduce the necessity of having to use more visible or coercive forms of power to ensure organizational goals are met and to quell resistance. The stronger such unobtrusive, cultural controls are, the less likely organizational norms will be transgressed, and the more comfortable managers will feel in delegating power (Westley, 1990). Thus, managers are able to provide employees with greater access to resources, yet still avoid opposition by reducing the will or inclination of employees to use their new-found power in an adversarial way.

In summary, by understanding the first three dimensions of power, we can see how business empowerment practices limit the devolution of power. Some, but certainly not all, elements of the first and second dimensions of power may be transferred to lower level employees, through wider access to some resources and processes; but the third dimension remains with senior managers. In the case of programs emphasizing the motivational approach discussed above, there is likely to be even less power delegated to employees than with the relational approach. However, any transfer of power that does occur is often limited to that 
between lower level managers and their subordinates. The power of senior level management, who usually dictate the form and timing of the overall empowerment initiative, remains untouched (Barker, 1993; Parker, 1993; O’Connor, 1995).

It is tempting to conclude that many companies are attracted to a fantasy version of empowerment and simultaneously repelled by the reality. How lovely to have energetic, dedicated workers who always seize the initiative (but only when “appropriate”), who enjoy taking risks (but never risky ones), who volunteer their ideas (but only brilliant ones), who solve problems on their own (but make no mistakes), who aren’t afraid to speak their minds (but never ruffle any feathers), who always give their very best to the company (but ask no unpleasant questions about what the company is giving back). How nice it would be, in short, to empower workers without actually giving them any power (Kizilos, 1990: 56).

In this sense, a three dimensional view enables us to see that although business empowerment programs promise employees power, they do not always deliver on these promises.

\section{Business Empowerment Practices: the Fourth Dimension of Power}

Foucault and many other postmodern writers would resist the notion of providing recommendations for empowerment practice; certainly, Foucault himself resisted any normative orientation (Alvesson \& Willmott, 1992a). Simply put, he would have questioned whether empowerment can exist in a world where power is everywhere; and using it may get you nowhere. Nonetheless, a Foucauldian perspective, which we have labelled a fourth dimension of our power, would acknowledge that practices that constitute business empowerment could result in some positive experiences for some individuals. If as Knights \& Morgan (1995: 194; 1991) note, power relations stimulate "a positive sense of self-discipline by transforming individuals 
into subjects who secure their sense of identity, meaning, and reality through participating in [certain] practices” might not empowerment relations produce a similar effect? In other words, might not many of the practices of empowerment -- those that grant autonomy, provide variety and challenge, relax formal controls, enhance the opportunity for personal initiative, generate an emotional attachment to collective goals -- constitute subjects who believe themselves more highly valued, who feel more excitement and passion in their work, and who derive a more rewarding work experience? In other words, individuals may enjoy being empowered.

So, rather than dismiss empowerment out of hand, as critical theorists often do, the fourth dimension draws our attention to the complexity and ambiguity of empowerment as it is experienced by those being empowered. While empowerment may contain a risk of exploitation, it also encompasses changes in the organizational environment that may improve the experience of working life for some, even if not all, employees.

\section{IMPLICATIONS FOR RESEARCH \& PRACTICE}

This section explores further some of the implications for research raised by the previous section's analysis. We first examine how critical researchers' three dimensional view of power exposes assumptions underlying the first two dimensions and, in so doing, offers a new agenda for mainstream management research. We then turn to Foucauldian ideas, based on the fourth dimension, and show how they might enhance critical research.

\section{Insights from Critical Research}

Critical theory would suggest that empowerment programs should be designed to enable disenfranchized members of society to overcome the forms and sources of domination associated with the first three dimensions of power. Such critical forms of empowerment are typically to be found outside the field of management, where they have been applied to a broad spectrum of 
groups: women, ethnic minorities, aboriginals, consumers, youths, alcoholics, ex-mental health patients, and the poor and illiterate (e.g., Alinsky, 1969, 1971; Solomon, 1976; Rose \& Black, 1985; Boyte \& Riessman, 1986; Freire, 1992). This view define empowerment as “a process, a mechanism by which people, organizations, and committees gain mastery over their affairs” (Rappaport (1987: 122). It is designed to counter existing power relations that result in the domination of subordinate groups by more powerful ones.

The common denominator in these programs is a process whereby traditionally disenfranchised groups become aware of the forces that oppress them and take action against them by changing the conditions in which they live and work. It involves not only the attainment of a greater sense of pride, self-respect, and personal efficacy, but also the acquisition of economic and political influence (Goski \& Belfry, 1991; Kizilos, 1990). Both subjective and objective changes are necessary: the former to help individuals recognize their powerlessness and motivate them to take action; the latter to enable individuals to acquire the necessary power (resources, access to the political system) to change the status quo (Bookman \& Morgan, 1988; Dacks \& Coates, 1988; Kizilos, 1990; Goski \& Belfry, 1991).

By seeking a redistribution of economic and political power, this category of empowerment program involves not merely participation in, but often resistance to, and conflict with, the governance structures that influence individuals’ lives (Alvesson \& Willmott, 1992a). [Empowerment connotes] a spectrum of political activity, ranging from acts of individual resistance to mass political mobilizations that challenge the basic power relations -- the social, political, and economic processes and institutions -in our society (Bookman \& Morgen, 1988: 4). 
The emphasis is on bottom-up, participatory, grassroots political activism, where a group organizes on its own behalf and for its own benefit (Bookman \& Morgan, 1988). Advocates of this perspective argue that empowerment has to be taken, not given, because of the inherent paradox in the empowerment of disenfranchied groups by more powerful actors. The very act of empowering someone else creates a dependency relationship which, by definition, is disempowering, particularly when the "empowerer" has significant power over the “empoweree” (e.g., Gruber \& Trickett, 1987; Simon, 1990).

According to our model, such approaches rest of on a belief that power is exercised through the three dimensions of power (the control of resources, processes, and meaning), hence empowerment can be achieved only through the acquisition of those dimensions of power denied to them i.e., meaning, processes, and resources. In contrast to business empowerment practices, these approaches to empowerment place a greater emphasis on both the transfer of the economic and political resources necessary to influence outcomes (first dimension) and to secure access to the political institutions and decision-making processes that influence the lives of the disenfranchised (second dimension). They also emphasize the need to manage meaning in a way that raises political consciousness concerning the sources of oppression (e.g., Rose \& Black, 1985; Boyte \& Riessman, 1986; Freire, 1992), for example through education, thereby creating a will to resist (third dimension). The rationale for this comprehensive approach is two-fold. First, if resources and processes are handed over, but individuals have no awareness of their oppression, they will not be able to use them effectively. Second, and of equal importance, is that if individuals are aware of, and seek to redress, the sources of their disenfranchisement, they will have little success without access to the processes and resources that govern their lives. 
The political dynamics of this more radical form of empowerment is thus quite different from business empowerment (table 3). As the disenfranchised become aware of and act against the sources of their powerlessness, resistance and conflict result. Business empowerment programs are, in contrast, designed to achieve organizational goals more effectively and more smoothly. ${ }^{2}$ They are intended to reduce conflict not increase it. The fact that business empowerment does not strive to invert the power balance between employers and employees; nor produce conflict by encouraging employees to resist the status quo; nor question the fundamental legitimacy of organizational goals should come as no surprise. Most managers and management theorists have no desire, intention, or expectation that they would operate in such a way.

[Table 3 here]

But, although managers might feel tempted to dismiss the critical perspective as inappropriate to business initiatives, this approach has much to contribute to business empowerment. Critical approaches illuminate the contradictions of business empowerment: namely that while the language of empowerment promises the acquisition of power in exchange for the different kinds of effort and responsibilites that such programs engender; practice limits the devolution of power to subordinates. It is in this discrepancy that the seeds of failure of business empowerment may lie. Researchers have noted that such "promise-making language” (Rousseau \& Parks, 1993: 20) creates beliefs about fairness (Rousseau \& Aquino, 1992) and creates a psychological contract (Rousseau \& Parks, 1993) between employer and employee. This contract encompasses the latter's beliefs concerning the commitments and obligations of the employment relationship. If the employer meets these perceived commitments, organizational loyalty is fostered, and cooperation and consensus are engendered (Levinson, 1962; Rousseau,

\footnotetext{
2 In referring to “organizational” goals, we do not dispute that they may be contested.
} 
1989). If, on the other hand, employees consider the organization to have breached the contract, trust and commitment can decline, and employees may withdraw from their obligations, all of which can have a negative effect on performance. (Also see the literature on realistic job previews [Tannenbaum et al., 1991; Wanous, et al., 1992], which shows that unmet expectations can have serious implications for satisfaction, commitment, and, in turn, performance). A critical approach shows, then, how the tendency of business empowerment to promise, but fail to deliver on, matters of power may be undermining the success of those programs in improving commitment and performance.

The critical perspective also highlights how mainstream management research often compounds this problem because of its lack of attention to power. Rather than deal with the complexity and discomfort (Pfeffer, 1992) engendered by the term power, research on empowerment from the mainstream management perspective has often sought to expunge all mention of it. Consider the following definition of empowerment from the motivational approach to empowerment, in which the link betwen power and empowerment is completely severed.

To empower means to give power to. Power, however, has several meanings. In a legal sense, power can mean authority, so that empowerment can mean authorization. Power also may be used to describe capacity, as in the self-efficacy definition of Conger \& Kanungo. However power also means energy. Thus to empower can mean to energize. (Thomas \& Velthouse, 1990: 667, original emphasis).

Through its emphasis on enhancing subjective feelings of self-efficacy, the motivational approach to empowerment downplays changes in broader working conditions that might devolve power (Skaggs \& Labianca, 1993). In Thomas and Velthouse’s (1990: 667) paper, for example, 
the section on changes in selected environmental variables such as delegation, job design and reward systems was curtailed due to “space limitations”. Critics argue that this approach represents a line of reasoning which, if extended, suggests that as long as employees can be made to believe they are empowered, it does not matter whether they actually are or not. In focussing their attention on overworked symbolic gestures while ignoring the substantive changes that should underlie them (e.g., Katz \& Kahn 1978: 388), managers can “claim to be empowering their workforce when in fact they are merely deceiving them” (Skaggs \& Labianca, 1993: 7).

Similarly, research on participation in decision making, which is an integral component of many empowerment programs, also avoids the issue of power. Empirical studies on participation have focussed primarily on collaborative decisions involving superior and subordinate, not the delegation of power by the former to the latter (Leana, 1987; Ledford \& Lawler, 1994; Wagner, 1994).

[P]articipation has commonly been operationally defined by researchers as joint decision making between superior and subordinate ... research has tended to focus exclusively on comparisons between joint decision making and autocratic arrangements in which subordinates are not included in any aspect of the decision making process. Conversely, research involving comparisons of other methods of involving subordinates in decision making is decidedly rare. One such method that has suffered from a particular lack of recognition by researchers is delegation (Leana, 1987: 228; original emphasis).

Writers suggest that, far from augmenting the power of subordinates, participation without delegation increases controls over employees (Tannenbaum, 1968; Scott \& Hart, 1979; Barker, 1993; Parker, 1993). This increase in management control does not, however, appear to translate 
into improved performance: Ledford \& Lawler (1994) point out that participation (collaborative decision making) does not improve satisfaction and performance unless it is accompanied by a broader decentralization of power, such as the delegation of authority, the opportunity to reject assigned goals, and voluntary participation (e.g. Leana, 1987; Latham et al., 1988; Vroom \& Jago, 1988; Leana et al., 1992).

In summary, a critical approach suggests that much of the research conducted in the mainstream management tradition tends to skirt the issue of power and, in so doing, adopts assumptions and protocols that restrict the redistribution of power in empowerment initiatives. This appears to occur despite the evidence mentioned above which suggests that the greater devolution of power may improve organizational performance. Rather than avoid power, it would appear that it is, perhaps, time for mainstream management research to address it more directly.

The first step for such a research agenda might be a more systematic verification of the types of practices used in business empowerment initiatives, using the power model to ascertain the degree to which power is devolved. Research might then provide a more precise assessment of the results of empowerment programs, and identify the nature of the relationship between these outcomes and the different practices that are adopted. In particular, the relative impact of participation and delegation on such variables as self-efficacy and outcome-expectancies might be examined. Such studies could establish whether there is a link between devolving the first and second dimensions of power and the success of empowerment. Studies might also investigate whether the term "empowerment" does raise expectations among employees concerning the acquisition of power and rewards, and whether and how these expectations impacts on the outcomes of the empowerment program. Research might also attempt to quantify the value 
created by empowerment practices and identify how such rewards might be distributed to employees.

Much of this research agenda means confronting the power behind empowerment, and tackling more directly the different ways in which power works. This may be difficult within the context of the positivistic science on which maintream management researchers traditionally rely. The second and, particularly, the third dimensions do not lend themselves to quantitative methodologies and neatly defined hypotheses. For example, Bachrach \& Baratz (1962) pointed out thirty years ago that the pluralists' emphasis on measuring the exercise of power contained inherent limitations concerning the tracking of the more elusive second face of power. If nondecision making presents difficulties, assessing the impact of managing meaning is even more problematic. Consequently, mainstream researchers may need to draw on more qualitative and ethnographic methodologies (e.g. such as those used by Pettigrew, 1973; Gaventa, 1980; Saunders, 1980; Hardy, 1985b; Barker, 1993) to explore fully the political dynamics of empowerment and its effect on organizational effectiveness.

\section{Insights from Foucauldian Research}

If a critical understanding challenges the limited devolution of power that typifies business empowerment programs, a Foucauldian perspective serves to inform the assumptions and limitations of the critical approach to empowerment. As noted in the previous section, critical theory traditionally has had emancipatory principles and has been judged by its ability to reveal the structures of oppression, and to offer emancipatory ideas that address them (Alvesson \& Willmott, 1992a). Under the rubric of “false consciousness” and "real interests”, critical theorists assumed themselves to be autonomous agents, and presumed to judge what their research subjects’ best interests were (see Lukes, 1974; Giddens, 1979; Benton, 1981; Knights \& 
Willmott, 1982; Hoy, 1986; Laclau \& Mouffe, 1987; Cooper \& Burrell, 1988). This approach has led to a number of problems even from the point of view of those people whom critical theorists deem to be their constituency: the disenfranchised.

Critical theory has, for example, been characterized by sophisticated, not to say convoluted, theorizations more notable for their employment of esoteric terminology than the practicalities of emancipation (Clegg 1989; Parker 1992; Nord \& Doherty 1994; Denzin, 1994). Only those forms of empowerment that involve a radical transformation in the distribution in power have been promoted, regardless of how disruptive, infeasible, or painful such changes might be (Alvesson \& Willmott, 1992a). Consequently, management empowerment initiatives have often been dismissed out of hand, as simply another, more sophisticated form of oppression (e.g., Parker, 1993) even though employees might experience some improvement in the quality of their working life. Such approaches privilege the academic researcher, schooled in "articulating” his or her thoughts thoughtfully, rationally, and logically, over the research subject (Fugelsang, 1973). The "exclamation" that communicates the experience of what the subject believes, sees, feels, and senses (Fugelsang, 1973) is translated and channelled into requisite, articulate categories provided by the well-trained researchers who emphasizes "experience-distance" terms, whose meaning lie in the observer's theory rather than the individual's experience, and which produce etic, abstract, non-contextualized interpretations (Denzin, 1994: 506; also Taylor, 1993). But the Foucauldian view of the inextricable link between power and knowledge challenges the idea of an all-knowing researcher who can offer objective, blanket advice for those labelled as oppressed and exploited.

Critical theory has also been criticized for engaging in "representational essentializing” (Clifford, 1992) where one aspect of a group's life is taken to represent it as a whole. For 
example, managers have often been ignored: dismissed as members of a homogenous dominant elite, unworthy of attention (Nord \& Jermier, 1992), and assumed to have an exclusive interest in exploiting workers (Knights \& Willmott, 1989). But managers may also experience distress and alienation as a result of empowerment. As Keller \& Dansereau (1995) point out, the need for control is necessary to individual well-being and integral to self-esteem. With empowerment comes a loosening of control, no matter how superficial, which undoubtedly adversely affects some managers. In fact, empowerment programs have the potential to impact upon managers in ways that should, ironically, elicit the sympathies of critical researchers: empowerment removes control from managers by making changes to work practices. As a result, their sense of identity which has been grounded in "traditional” management authority and practice, is threatened. Moreover, the scope for management resistance is limited because the rhetoric of empowerment has become intertwined with ideas of "good" and "enlightened" management practice. Managers would appear, then, to be ideal subjects for critical studies of empowerment.

In summary, while critical theorists may automatically condemn business empowerment as a management ploy to increase its power and exploit workers more effectively, and may dismiss employees involved in such initiatives as simple-minded victims, Foucauldian insights suggest that this is no longer a tenable position. Articulation should not overwhelm exclamation; the academic researcher should not muffle, under the rubric of a "false" consciousness that masks "real" interests, the voices of those who might wish to convey the positive benefits of their current status. Nor should it silence the voices of those who experience dislocation and discontinuity despite a supposedly privileged position.

Critical research might also consider how to make organizations more empowering for employees, for example, by exploring how the wealth created through empowerment might be 
assessed and then distributed in ways that are meaningful to those employees. It could also examine how empowerment affects individuals' identities in ways they experience as positive. In this regard, critical research needs to reorient its traditional concerns with "workers" to include work involving managers, since empowerment may threaten managers, especially lower-level ones, even more than employees. Those who have previously been successful in hierarchical organizations, who define themselves in the context of more hierarchical, authoritarian styles of management, may find empowerment particularly repressive. So, critical scholars might add managers to their research agenda (Alvesson \& Willmott, 1992a; Nord \& Jermier, 1992).

\section{CONCLUSIONS}

We have shown that empowerment means quite a different thing to managers and mainstream management researchers than it does to critical theorists. Cullen \& Townley (1994) argue that the former have emphasized the transitive use of the verb: to grant or bestow power, while the latter have adopted the reflexive usage: to gain or assume power over someone else. These divergent understandings have arisen because power, which is integral to empowerment, also has different connotations for these groups. From the mainstream management perspective, power is legitimate and functional, and can be shared, ostensibly to everyone's benefit. Empowerment can thus be used as a tool to motivate employees to achieve organizational goals. For critical theorists, power is domination, and so, empowerment must provide the means to combat the sources of domination. Power stands as a zero sum game: to gain it, somebody else has to relinquish it. Meanwhile, the Foucauldian perspective suggests that critical theory must resist its tendency to judge from on high. For some employees, empowerment may offer new, more meaningful identities and experiences. Foucault's insights serve to remind us that researchers hold no monopoly on the truth but are subject to power relations like everyone else. 
We have also suggested that the disappointing results of business empowerment may be partly due to the mainstream management research's reluctance to tackle the link between power and empowerment. A critical analysis of power offers insight into the reasons behind this impasse. It also offers, perhaps ironically, a possible solution by indicating how the third dimension of power can be used to exercise managerial control when extending access to resources and processes. If managers start to use power in more sophisticated and less visible ways, theory that is critically" informed becomes ever more vital to management theory and practice. The depoliticization of empowerment in mainstream management makes employees particularly vulnerable to the abuse of power under the rhetoric of empowerment. A critical approach, albeit informed with postmodern sensibilities (Kincheloe \& MacLaren, 1994), renders the political dynamics of empowerment visible by putting power back into the equation.

Finally, it must be acknowledged that postmodernist theories are not beyond criticism either: the barriers noted by some postmodern theorists in transforming existing power relations have led some theorists to opt out of emancipatory discourse completely, emphasizing the limits of resistance rather than the possibilities of emancipation (see Hoy, 1986: Said, 1986; Walzer, 1986; White, 1986; Ashley, 1990; also Jermier et al., 1994) and eschewing practical implications (Marsden \& Townley, 1996). For these theorists, it is well to remember that although Foucault may “deny that protest against oppression requires any neutral standpoint of justification at all. The fact is the people often do resist what they regard as oppressive circumstances....The fact that one cannot guarantee the outcome of any such resistance is no argument against it” (Sawicki, 1991: 99-100). This includes translating postmodern insights into a recognizable and practical form, and sharing them with the people who work in the organizations that we study. 
Table 1

The Dimensions of Power

\begin{tabular}{|c|c|c|c|c|}
\hline & $\begin{array}{l}\text { First } \\
\text { Dimension }\end{array}$ & $\begin{array}{l}\text { Second } \\
\text { Dimension }\end{array}$ & $\begin{array}{l}\text { Third } \\
\text { Dimension }\end{array}$ & $\begin{array}{l}\text { Fourth } \\
\text { Dimension }\end{array}$ \\
\hline $\begin{array}{l}\text { examples of } \\
\text { intellectual } \\
\text { traditions }\end{array}$ & $\begin{array}{l}\text { Dahl (1957); } \\
\text { also } \\
\text { Polsby (1963) }\end{array}$ & $\begin{array}{l}\text { Bachrach \& } \\
\text { Baratz (1962, } \\
\text { 1963, 1970) }\end{array}$ & $\begin{array}{l}\text { Lukes (1974); } \\
\text { also Fox (1973) }\end{array}$ & $\begin{array}{l}\text { Foucault (1977, } \\
\text { 1980, 1982, } \\
1984)\end{array}$ \\
\hline $\begin{array}{l}\text { examples of } \\
\text { management \& } \\
\text { organizational } \\
\text { research based on } \\
\text { similar } \\
\text { assumptions to } \\
\text { these intellectual } \\
\text { traditions } \\
\text { regarding the use } \\
\text { and nature of } \\
\text { power }\end{array}$ & $\begin{array}{l}\text { Thompson } \\
\text { (1956) } \\
\text { Pettigrew } \\
\text { (1973) } \\
\text { Pfeffer \& } \\
\text { Salancick } \\
\text { (1974) } \\
\text { Hickson et al. } \\
\text { (1971) } \\
\text { Pfeffer (1981) }\end{array}$ & $\begin{array}{l}\text { Crenson (1971) } \\
\text { Hunter (1980) }\end{array}$ & $\begin{array}{l}\text { Clegg (1975) } \\
\text { Pettigrew } \\
(1979) \\
\text { Ranson et al. } \\
\text { (1980) } \\
\text { Hardy (1985a) } \\
\text { Forester (1989) } \\
\text { Martin (1992) }\end{array}$ & $\begin{array}{l}\text { Cooper \& } \\
\text { Burrell (1988) } \\
\text { Knights \& } \\
\text { Morgan (1991) } \\
\text { Knights (1992) } \\
\text { Knights \& } \\
\text { Willmott (1993) } \\
\text { Hassard (1993) }\end{array}$ \\
\hline $\begin{array}{l}\text { focus of } \\
\text { management and } \\
\text { organizational } \\
\text { research }\end{array}$ & $\begin{array}{l}\text { the use of } \\
\text { resources and } \\
\text { decision } \\
\text { outcomes }\end{array}$ & $\begin{array}{l}\text { nondecision } \\
\text { making in } \\
\text { organizations }\end{array}$ & $\begin{array}{l}\text { the management } \\
\text { of meaning } \\
\text { and/or } \\
\text { structuration }\end{array}$ & $\begin{array}{l}\text { disciplinary } \\
\text { power and } \\
\text { normalizing } \\
\text { discourses }\end{array}$ \\
\hline $\begin{array}{l}\text { contribution of } \\
\text { management and } \\
\text { organizational } \\
\text { research }\end{array}$ & $\begin{array}{l}\text { helps to } \\
\text { explain } \\
\text { decision } \\
\text { outcomes as } \\
\text { political rather } \\
\text { than rational }\end{array}$ & $\begin{array}{l}\text { helps to explain } \\
\text { how power is } \\
\text { mobilized } \\
\text { through } \\
\text { decision } \\
\text { processes }\end{array}$ & $\begin{array}{l}\text { helps to explain } \\
\text { absence of } \\
\text { resistance }\end{array}$ & $\begin{array}{l}\text { helps to explain } \\
\text { limits of power } \\
\text { and resistance }\end{array}$ \\
\hline
\end{tabular}


Table 2

Empowerment and the Dimensions of Power

\begin{tabular}{|c|c|c|c|c|}
\hline & $\begin{array}{l}\text { First } \\
\text { Dimension }\end{array}$ & $\begin{array}{l}\text { Second } \\
\text { Dimension }\end{array}$ & $\begin{array}{l}\text { Third } \\
\text { Dimension }\end{array}$ & $\begin{array}{l}\text { Fourth } \\
\text { Dimension }\end{array}$ \\
\hline $\begin{array}{l}\text { Power of A } \\
\text { over B: }\end{array}$ & $\begin{array}{l}\text { management of } \\
\text { resource } \\
\text { dependencies }\end{array}$ & $\begin{array}{l}\text { management of } \\
\text { decision making } \\
\text { processes }\end{array}$ & $\begin{array}{l}\text { management of } \\
\text { meaning }\end{array}$ & $\begin{array}{l}\text { none, power is } \\
\text { embedded in the } \\
\text { system }\end{array}$ \\
\hline $\begin{array}{l}\text { Interaction } \\
\text { between A and } \\
\text { B: }\end{array}$ & overt conflict & $\begin{array}{l}\text { overt or covert } \\
\text { conflict }\end{array}$ & $\begin{array}{l}\text { apparent } \\
\text { cooperation }\end{array}$ & local struggles \\
\hline $\begin{array}{l}\text { Reason for B's } \\
\text { failure to } \\
\text { influence } \\
\text { outcomes: }\end{array}$ & $\begin{array}{l}\text { B is aware of } \\
\text { the issue and } \\
\text { able to get it to } \\
\text { the decision } \\
\text { arena, but is } \\
\text { unable to use it } \\
\text { effectively to } \\
\text { influence } \\
\text { outcomes }\end{array}$ & $\begin{array}{l}\mathrm{B} \text { is aware of the } \\
\text { issue but unable } \\
\text { to get it to the } \\
\text { decision arena }\end{array}$ & $\begin{array}{l}\mathrm{B} \text { is unaware of } \\
\text { the issue and, } \\
\text { so, has no will } \\
\text { resist }\end{array}$ & $\begin{array}{l}\text { Both A \& B are } \\
\text { prisoners of the } \\
\text { prevailing } \\
\text { discourses of } \\
\text { power although } \\
\text { A may derive } \\
\text { greater } \\
\text { advantage from } \\
\text { them }\end{array}$ \\
\hline $\begin{array}{l}\text { Empowerment } \\
\text { of B requires: }\end{array}$ & $\begin{array}{l}\text { acquisition of } \\
\text { resources and } \\
\text { ability to } \\
\text { mobilize them }\end{array}$ & $\begin{array}{l}\text { ability to gain } \\
\text { access to the } \\
\text { decision arena }\end{array}$ & $\begin{array}{l}\text { consciousness- } \\
\text { raising and } \\
\text { “delegitimation } \\
\text { ” strategies to } \\
\text { create will to } \\
\text { resist }\end{array}$ & $\begin{array}{l}\text { empowerment in } \\
\text { the sense of } \\
\text { freedom from } \\
\text { power effects is } \\
\text { not possible } \\
\text { although local } \\
\text { struggles may } \\
\text { produce more } \\
\text { positive } \\
\text { experiences }\end{array}$ \\
\hline
\end{tabular}


Table 3

Comparing Critical and Mainstream Empowerment Practices

\begin{tabular}{|c|c|c|}
\hline & $\begin{array}{l}\text { Critical Empowerment } \\
\text { Practices }\end{array}$ & $\begin{array}{l}\text { Mainstream Empowerment } \\
\text { Practices }\end{array}$ \\
\hline First Dimension & $\begin{array}{l}\text { Key resources (e.g. } \\
\text { information, education, } \\
\text { financial) are handed over to } \\
\text { or taken over by less } \\
\text { powerful groups }\end{array}$ & $\begin{array}{l}\text { Some resources are handed } \\
\text { over to employees (e.g. } \\
\text { information, financial) but } \\
\text { other resources (e.g. right to } \\
\text { hire and fire, financial) } \\
\text { retained by management }\end{array}$ \\
\hline Second Dimension & $\begin{array}{l}\text { Access to decision making } \\
\text { processes by less powerful } \\
\text { groups is secured or/and new } \\
\text { processes, with broader } \\
\text { representation, are created }\end{array}$ & $\begin{array}{l}\text { Access to decision making } \\
\text { processes is extended to } \\
\text { employees but parameters } \\
\text { are established to set limits } \\
\text { on autonomy }\end{array}$ \\
\hline Third Dimension & $\begin{array}{l}\text { The legitimacy of the status } \\
\text { quo and organizational or } \\
\text { societal goals are directly } \\
\text { confronted through } \\
\text { consciousness-raising and } \\
\text { "delegitimating" actions and } \\
\text { language }\end{array}$ & $\begin{array}{l}\text { The fundamental legitimacy } \\
\text { of organizational imperatives } \\
\text { is never questioned, although } \\
\text { some change in the } \\
\text { respective responsibilities of } \\
\text { management and employees } \\
\text { may occur; commitment to } \\
\text { organizational goals is } \\
\text { increased through } \\
\text { legitimating actions and } \\
\text { language }\end{array}$ \\
\hline Outcome & $\begin{array}{l}\text { Empowerment is intended to } \\
\text { produce resistance to } \\
\text { prevailing power distribution } \\
\text { and may result in conflict as } \\
\text { subordinate actors gain } \\
\text { power if dominant actors fail } \\
\text { to respond }\end{array}$ & $\begin{array}{l}\text { Empowerment is intended to } \\
\text { facilitate achievement of } \\
\text { organizational goals and any } \\
\text { increase in employee power } \\
\text { should not produce any } \\
\text { increase in conflict }\end{array}$ \\
\hline
\end{tabular}




\section{References}

Alinsky, S.D. 1969. Reveille for radicals. New York: Vintage Books.

Alinsky, S.D. 1971. Rules for radicals. New York: Vintage Books.

Alvesson, M. 1984. Questioning rationality and ideology: On critical organization theory. International Studies of Management and Organizations. 14(1): 61-79.

Alvesson, M. \& Deetz, S. 91996. Critical theory and postmodernism approaches to organizational studies. In Clegg, S.R., Hardy, C. \& Nord, W.R. (eds.) Handbook of Organization Studies. 191-217, London: Sage.

Alvesson, M. \& Willmott, H. 1992a. On the idea of emancipation in management and organization studies. Academy of Management Review, 17(3): 432-464.

Alvesson, M. \& Willmott, H. (eds). 1992b. Critical management studies. London: Sage.

Ashley, D. 1990. Habermas and the completion of the "project of modernity” In Turner, B.S. (ed.) Theories of modernity \& post modernity. 88-107, London: Sage.

Astley, W. G. \& Sachdeva, P.S. 1984. Structural sources of intraorganizational power: A theoretical synthesis. Academy of Management Review, 9(1): 104-113.

Bachrach, P. \& Baratz, M. S. 1962. The two faces of power. American Political Science Review, 56, 947-952.

Bachrach, P. \& Baratz, M.S. 1963. Decisions and nondecisions: An analytical framework, American Political Science Review, 57: 641-51.

Bachrach, P. \& Baratz, M.S. 1970. Power and poverty. London: Oxford University Press.

Bandura, A. 1986. Social foundations of thought and action: A social cognitive theory.

Englewood Cliffs, NJ: Prentice-Hall.

Barbalet, J.M. 1988. Power and Resistance. British Journal of Sociology, 36(4), 531-548.

Barker, J.R. 1993. Tightening the iron cage: concertive control in self-managing teams. Administrative Science Quarterly, 38, 408-437.

Beatty, R.W. \& Ulrich, D.O. 1991. Re-energizing the mature organization. Organizational Dynamics, 20(1): 16-30.

Belasco, J.A. 1989. Masters of empowerment. Executive Excellence, 6(3): 11-12. 
Bell, C. \& Zemke, R. 1988. Do service procedures tie employees hands? Personnel Journal, 67(9): 77-83.

Benton, T. 1981. Objective interests and the sociology of power. Sociology, 15 (2): 161-84.

Bernstein, A.J. 1992. Why empowerment programs often fail. Executive Excellence, 9(7): p.5.

Beyer, J.M., Dunbar, R.L.M. \& Meyer, A.D. 1988. Comment: The concept of ideology in organizational analysis. Academy of Management Review, 13 (3): 489-89.

Block, P. 1990. How to be the new kind of manager. Working Woman, 15(7): 51-56.

Bookman, A. \& Morgan, S. 1988. Women and the politics of empowerment. Philadelphia: Temple University Press.

Bowen, D.E. \& Lawler, E.E. 1992. The empowerment of service workers: What, why, how, and when. Sloan Management Review, 33(3): 31-39.

Boyte, H. C. \& Riessman, F. 1986. The new populism: The politics of empowerment. Philadelphia: Temple University Press.

Bradshaw-Camball, P. \& Murray, V., 1991. Illusions and other games: A trifocal view of organizational politics. Organization Science, 2(4): 379-398.

Brown, D. 1992. Why participative management won't work here. Management Review, 81(6): 42-46.

Brown, T.L. 1990. Fearful of empowerment: Should managers be terrified? Industry Week, 239(12): 12.

Brymer, R.A. 1991. Employee empowerment: A guest-driven leadership strategy. Cornell Hotel \& Restaurant Administration Quarterly, 32(1): 58-68.

Burke, W.W. 1986. Leadership as empowering others. In Srivasta, S. \& Associates, (eds.) Executive power, San Francisco: Jossey-Bass, 51-77.

Cardy, R.L., Dobbins, G.H. \& Carson, K.P. 1995. TQM and HRM: Improving Performance Appraisal, Research, Theory and Practice. Canadian Journal of Administrative Sciences, 12(2) 106-115.

Carr, C. 1991. Managing self-managed workers. Training and Development, 45(9): 36-42.

Clegg, S. 1975. Power, rule and domination. London: Routledge.

Clegg, S. 1989. Frameworks of power. London: Sage. 
Clifford, J. 1992. Travelling cultures. In L. Grossberg, Nelson, C. \& Treichler, P.A. (eds.) Cultural studies. New York: Routledge.

Conger, J.A. \& Kanungo, R.N. 1988. The empowerment process: Integrating theory and practice. Academy of Management Review, 13(3): 471-482.

Cooper, R. \& Burrell, G. 1988. Modernism, postmodernism and organizational analysis: An introduction. Organization Studies, 9(1), 91-112.

Crenson, M.A. 1971. The un-politics of air pollution: A study of nondecision making in the cities. Baltimore: John-Hopkins Press, 1971.

Crozier, M. 1964. The bureaucratic phenomenon. Chicago: University of Chicago Press.

Cullen, D. \& Townley, B. 1994. Autonomy and empowerment: New wine in old bottles. Paper presented at the Western Academy of Management Santa Fe, NM.

Dacks, G. \& Coates, K. 1988. Northern communities: The prospects for empowerment. Alberta: Boreal Institute for Northern Studies.

Dahl, R. 1957. The concept of power. Behavioral Science, 20: 201-215.

Dean, J.W. \& Bowen, D.E. 1994. Management theory and total quality: Improving research and practice through theory development. Academy of Management Review, 19(3): 392-418.

Deetz, S. 1992a. Democracy in an age of corporate colonization: Developments in communication and the politics of everyday life. Albany, NY: State University of New York.

Deetz, S. 1992b Disciplinary power in the modern corporation. In Alvesson, M. \& Willmott, H. (eds.) Critical Management Studies, 21-45. London: Sage

Delbridge, R., Turnbull, P. \& Wilkinson, B. 1992. Pushing back the frontiers. New Technology and Employment, 7(2): 97-106, 1992.

Denzin, N. 1994. The art and politics of interpretation. In Denzin, N.K. \& Lincoln, Y.S. (eds.) Handbook of Qualitative Research, 500-515, London: Sage.

Denzin, N.K \& Lincoln, Y.S. 1994. Entering the field of qualitative research. In Denzin, N.K. \& Lincoln, Y.S. (eds.) Handbook of Qualitative Research, 1-18, London: Sage.

Doyle, F.P. 1990. People-Power: The global human resource challenge for the 90's. Columbia Journal of World Business, 25(1): 36-45. 
Dreyfus, H.L. \& Rabinow, P. 1982. Michel Foucault: Beyond structuralism and hermeneutics. Brighton: Harvester.

Early, V. 1991. Empowering organizations. Executive Excellence, 8(2): 13-14.

Eccles, R. \& Nohria, N. 1993. Beyond the hype. Cambridge, Mass: Harvard Business School.

Eccles, T. 1993. The deceptive allure of empowerment. Long Range Planning, 26(6): 13-21.

Eisman, R. 1991. Power to the people. Incentive, 165(10): 116.

Eubanks, P. 1991. Employee empowerment key to culture change. Hospitals, 65(24): 40.

Feldman, D.C. \& Leana, C.R. 1994. Better practices in managing layoffs. Human Resource Management, 33(2): 239-60

Fleming, P.C. 1991. Empowerment strengthens the rock. Management Review. 80(12): 34-37.

Ford, R.C. \& Fottler, M.D. 1995. Empowerment: A matter of degree. Academy of Management Executive, 9(3), 21-31.

Forester, J. 1989. Planning in the face of power. Berkely: University of California Press.

Forester, J. 1992. “Critical ethnography: On fieldwork in a Habermasian way.” In Alvesson, M. \& Willmot H. (eds.) Critical Management Studies, 46-65, London: Sage.

Foucault, M. 1977. Discipline and punish: The birth of the prison. Harmondsworth: Penguin.

Foucault, M. 1980. Power/Knowledge: Selected interviews and other writings 1972-1977.

Gordon, C. (ed.) Brighton: Harvester Press.

Foucault, M. 1982. The subject and power. In Dreyfus, H.L. \& Rabinow, P., Michel Foucault: Beyond structuralism and hermeneutics, 208-226. Brighton: Harvester.

Foucault, M. 1984. The history of sexuality: An introduction, Harmondsworth: Penguin.

Fox, A. 1973. Industrial relations: A social critique of pluralist ideology. In Child, J. (ed.) Man and Organization, London: Allen and Unwin.

Foxman, L.D. \& Polsky, W.L. 1991. Share the power. Personnel Journal, 70(9): 116-120.

Freeman, S.J. 1994. Organizational downsizing as convergence and reorientation: Implications for human resource management. Human Resource Management, 33(2): 213-238.

Freire, P. 1992. Pedagogy of the oppressed. New York: Continuum. 
French, J.R.P. \& Raven, B. 1968. The bases of social power. In Cartwright, D. \& Zander, A. (eds.) Group dynamics. New York: Harper and Row.

Frost, P.J. \& Egri, C.P. 1989. The political process of innovation. In Cummings, L.L. \& Staw, B.M. (eds.) Research in organizational behavior. Greenwich, CT: JAI Press.

Frost, P.J. 1987. Power, politics and influence. In Jablin, F.M., Putnam, L.L, Roberts, K.H., Porter L.W. (eds.) Handbook of organizational communications: An interdisciplinary perspective. London: Sage.

Fugelsang, A. 1973. Applied communication in developing countries, Uppsala: The Dag Hammarskjold Foundation.

Gandz, J. 1990. The employee empowerment era. Business Quarterly, 55(2): 74-79.

Gaventa, J. 1980. Power and powerlessness. London: Oxford University Press.

Giddens, A. 1979. Central problems in social theory. London: MacMillan.

Gonring, M.P. 1991. Communication makes employee involvement work. Public Relations Journal, 47(11): 38-40.

Goski, K.L. \& Belfry, M. 1991. Achieving competitive advantage through employee empowerment. Employment Relations Today, 18(2): 213-220.

Gray, B. \& Ariss. S. 1985. Politics and strategic change across organizational life cycles, Academy of Management Review, 10(4): 707-723.

Gruber, J. \& Trickett, E.J. 1987. Can we empower others? The paradox of empowerment in the governing of an alternative public school. American Journal of Community Psychology, 15(3): 353-371.

Hancock, M.D., Logue, J. \& Schiller, B. 1991. Managing modern capitalism: Industrial renewal and workplace democracy in the United States and Western Europe. New York: Praeger.

Hardy, C. 1985a. The nature of unobtrusive power. Journal of Management Studies, 22(4): 384399.

Hardy, C. 1985b. Managing organizational closure. Aldershot, England: Gower Press.

Hardy, C., 1994. Power and politics in organizations. In Hardy, C. Managing strategic action: Mobilizing change, London: Sage. 
Hardy, C. \& Clegg, S. 1996. Some dare call it power. In Clegg, S., Hardy, C. \& Nord, W. (eds.) Handbook of organizational studies. London: Sage.

Hardy, C. \& Redivo, F. 1994. Power and organizational development: A framework for organizational change. Journal of General Management, 20(2): 1-13.

Hassard, J. 1993. Sociology and organization theory: Positivism, paradigms and postmodernity, London: Sage.

Hickson, D.J., Butler, R. J., Cray, D., Mallory, G.R. \& Wilson, D.C. 1986. Top decisions: Strategic decision-making in organizations. San Francisco, Ca.: Jossey-Bass.

Hickson, D.J., Hinings, C.R., Lee, C.A., Schneck, R.E. \& Pennings, J.M. 1971. A strategic contingencies theory of intraorganizational power. Administrative Science Quarterly, 16: 216229.

Hollway, W. 1991. Work psychology and organizational behaviour: Managing the individual at work. London: Sage.

Hoy, D.C. 1986. Power, repression, progress: Foucault, Lukes, and the Frankfurt School. In Hoy, D.C. (ed.) Foucault: A critical reader. 123-147, Oxford: Basil Blackwell.

Humphrey, J.W. 1991. A time of 10,000 leaders. Executive Excellence, 8(6): 17-18.

Hunter, D.J. 1980. Coping with uncertainty. Chichester, England: Research Studies Press.

Hyman, R. \& Brough, I. 1975. Social values and industrial relations, Oxford, England: Basil Blackwell.

IDE International Research Group. 1993. Industrial Democracy in Europe Revisited. Oxford: Oxford University Press.

Izraeli, Dafna M. \& Todd D. Jick. 1986. The art of saying no: Linking power to culture. Organization Studies, 7 (2): 171-192.

Jencks, C. 1989. What is post-modernism? 3rd ed. (rev. enlarged). New York: Academy Editions/St. Martins Press.

Jermier, J.M., Nord, W.R. \& Knights, D. (eds.) 1994. Resistance and power in organizations: agency, subjectivity and the labour process. London: Routledge.

Katz, D. \& Kahn, R.L. 1978. The Social Psychology of Organizations. New York: John Wiley, second edition. 
Keller, T. \& Dansereau, F. 1995. Leadership and Empowerment: A Social Exchange Perpective. Human Relations, 48(2): 127-147.

Kerfoot, D. \& Knights, D. 1993. Management, masculinity and manipulation: From paternalism to corporate strategy in financial services in Britain. Journal of Management Studies, 30(4): 659677.

Kincheloe, J.L. \& McLaren, P.L. 1994. Rethinking critical theory and qualitative research. In Denzin, N.K. and Lincoln, Y.S. (eds.) Handbook of Qualitative Research, 138-157, London: Sage.

Kizilos, P. 1990. Crazy about empowerment? Training, 27(12): 47-56.

Knights, D. 1992. Changing spaces: The disruptive impact of a new epistemological location for the study of management. Academy of Management Review, 17(3): 514-536.

Knights, D. \& Murray, F. 1992. Politics and pain in managing information technology: A case study from insurance. Organization Studies, 13(2): 211-288.

Knights, D. \& Morgan, G. 1991. Strategic discourse and subjectivity: Towards a critical analysis of corporate strategy in organisations. Organization Studies, 12(3): 251-273.

Knights, D. \& Morgan, G. 1995. Strategy under the microscope: Strategic management and IT in financial services. Journal of Management Studies, 32(2), 191-214.

Knights, D. \& Willmott, H. 1982. Power, values and relations: A comment on Benton. Sociology, 16(4): 578-585.

Knights, D. \& Willmott, H. 1989. Power and subjectivity at work: From degradation to subjugation in social relations. Sociology, 23(4): 535-558.

Laclau, E. 1988. Politics and the limits of modernity. In A. Ross (ed.) Universal abandon: The politics of postmodernism. Minneapolis: University of Minnesota Press.

Laclau, E. \& Mouffe, C . 1987. Postmodernism without apologies. New Left Review 166: 79106.

Latham, G.P., Erez, M. \& Locke, E.A. 1988. Resolving scientific disputes by the joint design of crucial experiments by the antagonists: Application of the Erez-Latham dispute regarding participation in goal-setting. Journal of Applied Psychology Monograph, 73: 753-772.

Lawler, E.E. 1992. The ultimate advantage: Creating the high-involvement organization San Francisco: Josey Bass. 
Leana, C.R. 1987. Power relinquishment versus power sharing: Theoretical clarification and empirical comparison of delegation and participation. Journal of Applied Psychology, 72: 22833.

Leana, C.R., Ahlbrandt, R.S. \& Murrel, A.J. 1992. The effects of employee involvement on unionized workers' attitudes, perceptions, and preferences in decision making. Academy of Management Journal, 35(4): 861-73.

Ledford, G.E. \& Lawler, E.E. 1994. Research on employee participation: Beating a dead horse? Academy of Management Review, 19(4): 633-636.

Leiba, S. \& Hardy, C. 1994. Employee empowerment: A seductive misnomer? In Hardy, C. Managing strategic action: Mobilizing change, London: Sage.

Levinson, H. 1962. Men, management, and mental health. Cambridge, MA: Harvard University Press.

Lichtenstein, N. \& Howell, J.H. 1993. Industrial democracy in America. Cambridge: Cambridge University Press.

Lukes, S. 1974. Power: A radical view. London: Macmillan.

MacMillan, I.C. 1978. Strategy formulation: Political concepts. St. Paul, MN: West.

Manz, C.C. 1990. Beyond self-managing work teams: Toward self-leading teams in the workplace. In Pasmore, W.A. \& Woodman, R.W. (eds.) Research in organizational change and development. Greenwich, CT: JAI Press, 273-299.

Marsden, R \& Townley, B. (1996). The Owl of Minerva: Reflections on Theory in Practice. In Clegg, S.R., Hardy, C. \& Nord, W.R. (eds.) Handbook of Organization Studies.659-675, London: Sage.

Martin, J. 1992. Cultures in Organizations: Three Perspectives. New York: Oxford University Press.

Matthes, K. 1992. Empowerment: Fact or fiction? HR Focus, 69(3): 1-6.

McCann, J.E. \& Galbraith, J.R. 1981. Interdepartmental relations. In Nystrom, P.C. \& Starbuck, W.H. (eds.) Handbook of organizational design, 2:60-84, New York: Oxford University Press.

McKenna, J.F. 1990. Smart scarecrows: The wizardry of empowerment. Industry Week, 239(14): 8-19.

McKenna, J.F., 1991a. America’s best plants: SPX. Industry Week, 240(20): 49-50. 
McKenna, J.F. 1991b. Failure: Managing the last taboo. Industry Week, 240(5): 12-16.

Mechanic, D. 1962. Sources of power of lower participants in complex organizations. Administrative Science Quarterly, 7(3): 349-64.

Mills, C. Wright. 1956. The Power Elite, New York: Oxford University Press. Norwood, NJ: Ablex.

Mumby, D.K. 1992. Two discourses on communication, power, and the subject: Jürgen Habermas and Michel Foucault. In Levine, G. (ed.) Construction of the self. New Brunswick, NJ: Rutgers University Press.

Narayanan, V.K. \& Fahey, L. 1982. The micro-politics of strategy formulation, Academy of Management Review, 7(1): 25-34.

Nord, W.R. \& Doherty, E.M. 1994. Towards an assertion perspective for empowerment: Blending employee rights and labor process theories. Unpublished paper: College of Business Administration, University of South Florida.

Nord, W.R. \& Jermier. J.M. 1992. Critical social science for managers? Promising and perverse possibilities. In Alvesson, M. \& Willmott, H. (eds.) Critical management studies. 202-222. London: Sage.

O’Connor, E.S. 1993. Paradoxes of participation: A textual analysis of case studies documenting employee involvement efforts. Paper presented at the Academy of Management, Atlanta.

O’Connor, E.S. 1995. Paradoxes of participation: A literary analysis of case studies on employee involvement. Organization Science, 16(5): 769-804.

Odiorne, G.S., 1991. Competence versus passion. Training and Development, 45(5): 61-64.

Parker, M. \& Slaughter, J. 1988. Managing by stress: The dark side of team concept, ILR Report, 26(1): 19-23.

Parker, M. 1993. Industrial relations myth and shop-floor reality: the "team concept: in the auto industry. In Lichtenstein, N. \& Howell, J.H. (eds.) Industrial democracy in America. Cambridge: Cambridge University Press.

Parry, G. \& Morriss, P. 1975. When is a decision not a decision? In Crewe, L. (ed.) British Political Sociology Yearbook, vol. 1. London, England: Croon Helm.

Penzer, E. 1991. The power of empowerment. Incentive, 165(5): 97-8, 138.

Perrow, Charles. 1979. Complex organizations: A critical essay. 2nd Ed. Glenview, Ill.: Scott, Foresman. 
Pettigrew, A.M. 1973. The politics of organizational decision making. London: Tavistock.

Pettigrew, A.M., 1979. On studying organizational cultures. Administrative Science Quarterly, 24: 570-81.

Pfeffer, J. 1981. Power in organizations. Marshfield, Mass.: Pitman.

Pfeffer, J. 1992. Understanding power in organizations. California Management Review, 35: 2950 .

Pfeffer, J. \& Salancik, G. 1974. Organizational decision making as a political process. Administrative Science Quarterly, 19: 135-51.

Polsby, N.W. 1963. Community power and political theory. New Haven: Yale University Press.

Porter L.W. \& Lawler, E.E., 1968. Managerial attitudes and performance. Homewood IL: Irwin.

Ranson, S., Hinings, C.R. \& Greenwood, R. 1980. The structuring of organizational structure. Administrative Science Quarterly, 25(1): 1-14.

Rappaport, J. 1987. Terms of empowerment/exemplars of prevention: Toward a theory for community psychology. American Journal of Community Psychology, 15(2): 121-148.

Roberts, J. 1991. Strategy and accounting in a UK conglomerate. Accounting, Organizations and Society, 15(1/2): 107-126.

Rose, S.M. \& Black, B.L. 1985. Advocacy and empowerment: Mental health care in the community. Boston: Routledge \& Kegan Paul.

Rosenau, P. M. (1992). Post-Modernism and the Social Sciences: Insights, Inroads, and Intrusions. Princeton, NJ, Princeton University Press.

Rousseau, D.M. and Aquino, K. 1992. Fairness and implied contract obligations in job terminations: The role of contributions, promises and performance. Journal of Organizational Behavior, 12, 287-299.

Rousseau, D.M. and Parks, J.M. 1993. The contracts of individuals and organizations. Research in Organizational Behavior, 15, pp. 1-43.

Said, Edward W. 1986 “Foucault and the imagination of power”, In Hoy, D.C. (ed.) Foucault: A critical reader. 149-155, Oxford: Basil Blackwell.

Salancik, G. and Pfeffer, J. 1974. The bases and use of power in organizational decision making. Administrative Science Quarterly, 19: 453-73. 
Saunders, P. 1980. Urban politics. London: Penguin.

Sawicki, J. 1991. Disciplining Foucault, London: Routledge.

Schaeffer, O. 1991. Empowerment as a business strategy. Executive Excellence, 8(10): 9-10.

Schattschneider, E.F. 1960. The semi-sovereign people. New York: Holt, Rinehart and Winston.

Schlossberg, H. 1991. Authors blast those who make excuses for poor business. Marketing News, 25(15): 5.

Schwenk, C.R. 1989. Linking cognitive, organizational and political factors in explaining strategic change, Journal of Management Studies. 26(2): 177-188.

Scott, W.G. \& Hart, D.K. 1979. Organizational America, Boston: Houghton Mifflin.

Shelton, K. 1991. People power. Executive Excellence, 8(12): 7-8.

Sheridan, J.N. 1991a. America’s best plants: Tennessee Eastman. Industry Week, 240(20): 59-60.

Sheridan, J.N. 1991b. A philosophy for commitment. Industry Week, 240(3): 11-13.

Sherwood, J.J. 1988. Creating work cultures with competitive advantage. Organizational Dynamics, 17: 4-27.

Simon, B.L. 1990. Rethinking empowerment. Journal of Progressive Human Sciences, 1(1): 27-37.

Skaggs, B.C. \& Labianca, G. 1993. Redefining empowerment: From a management-centered construct to economic democracy. Paper presented at the Academy of Management, Atlanta.

Smart, B. 1985. Michel Foucault, London: Tavistock.

Smart, B. 1986. The politics of truth and the problem of hegemone. In Hoy, D.C. (ed.) Foucault: A critical reader, 157-173. Oxford: Basil Blackwell.

Solomon, B.B. 1976. Black empowerment: Social work in oppressed communities. New York: Columbia University Press.

Spencer, B.A. 1994. Models of organization and total quality management: A comparison and critical evaluation. Academy of Management Review, 19(3): 446-71.

Stewart, T.A. 1989. New ways to exercise power. Fortune, 6 November: 48-53. 
Stopford, J. \& Baden-Fuller, C. 1990. Corporate rejuvenation. Journal of Management Studies, 27: 399-415.

Tannenbaum, A.S. 1968. Control in organizations. New York: McGraw Hill.

Tannenbaum, S.I., Mathieu, J.E., Salas, E. \& Cannon-Bowers, J.A. 1991. Meeting trainees’ expectations: The influence of training fulfilment on the development of commitment, selfefficacy, and motivation. Journal of Applied Psychology, 76(6): 739-769.

Taylor, P.V. 1993. The texts of Paulo Freire. Milton Keynes: Open University Press

Thomas, K.W. \& Velthouse, B.A. 1990. Cognitive elements of empowerment: An "interpretive” model of intrinsic task motivation. Academy of Management Review, 15(4): 666-81.

Thompson, J.D. 1956. Authority and power in identical organizations. American Journal of Sociology, 62: 290-301.

Topaz, L. 1989/90. Empowerment: Human resource management in the 90 's. Management Quarterly, 30(4): 3-8.

Townley, B. 1993. Reframing human resource management: Power, ethics and the subject at work. London: Sage.

Turner, B.S. 1990. Theories of modernity and post modernity. London: Sage.

Velthouse, B.A. 1990. Creativity and empowerment: A complementary relationship. Review of Business, 12(2): 13-18.

Vloeberghs, D. \& Bellens, J. (1996). Human resource aspects of ISO 9000 in Belgian organizations. International Journal of Human Resource Management, 7(2), 413-436.

Von der Embse, T.J. 1989. Transforming power into empowerment. Manage, 41(3): 25-28.

Vroom, V.H. \& Jago, A.G. 1988. The new leadership: Managing participation in organizations. Englewood Cliffs: Prentice Hall.

Vroom, V.H., 1964. Work and Motivation, New York: John Wiley.

Wagner, J.A. 1994. Participation's effects on performance and satisfaction: A reconsideration of research evidence. Academy of Management Review, 19(2) 312-330.

Waldman, D.A. 1994. The contributions of total quality management to a theory of work performance. Academy of Management Review, 19(3): 510-36. 
Walzer, M. 1986. The politics of Michel Foucault, In Hoy, D.C. (ed.) Foucault: A critical reader. 51-68, Oxford: Basil Blackwell.

Wanous, J., Poland, D., Premack, S.L. \& Davis, K. 1992. The effects of met expectations on newcomer attitudes and behaviors: A review and meta-analysis. Journal of Applied Psychology, 77: 288-297.

Weber, M. 1947. The theory of social and economic organization. New York: Free Press.

Weiss, R. M. \& Miller, L.E. 1987. The concept of ideology in organizational analysis: The sociology of knowledge or the social psychology of beliefs? Academy of Management Review, 12(1): 104-116.

Welter, T.R. 1991a. A winning team begins with you. Industry Week, 240(9): 35-42.

Welter, T.R. 1991b. America’s best plants: Lord Corp. Industry Week, 240(20): 44-46.

Westley, F. 1990. Middle managers and strategy: The microdynamics of inclusion. Strategic Management Journal, 11: 337-351.

White, Stephen K. 1986. Foucault's challenge to critical theory. American Political Science Review, 80(2): 419-432, June,

Willmott, H. 1993. Strength is ignorance; slavery is freedom: Managing culture in modern organizations. Journal of Management Studies. 30(4): 515-552. 


\section{University Library}

\section{- M M I E E R VA A gateway to Melbourne's research publications}

Minerva Access is the Institutional Repository of The University of Melbourne

Author/s:

Hardy, C; Leiba-O'Sullivan, S

Title:

The power behind empowerment: Implications for research and practice

Date:

1998-04-01

Citation:

Hardy, C. \& Leiba-O'Sullivan, S. (1998). The power behind empowerment: Implications for research and practice. HUMAN RELATIONS, 51 (4), pp.451-483. https:// doi.org/10.1177/001872679805100402.

Persistent Link:

http://hdl.handle.net/11343/116092 